\title{
Association of candidate gene polymorphisms with milk technological traits, yield, composition, and somatic cell score in Italian Holstein-Friesian sires
}

\author{
E. Viale, ${ }^{*}$ F. Tiezzi, † F. Maretto, ${ }^{*}$ M. De Marchi, ${ }^{*}$ M. Penasa, ${ }^{*}$ and M. Cassandro*1 \\ *Department of Agronomy, Food, Natural Resources, Animals and Environment (DAFNAE), University of Padova, Viale dell'Università 16, \\ 35020 Legnaro (PD), Italy \\ †Department of Animal Science, North Carolina State University, Raleigh 27695
}

\section{ABSTRACT}

Advances in DNA-based marker technology have enabled the identification of genomic regions underlying complex phenotypic traits in livestock species. The incorporation of detected quantitative trait loci into genetic evaluation provides great potential to enhance selection accuracies, hence expediting the genetic improvement of economically important traits. The objective of the present study was to investigate 96 single nucleotide polymorphisms (SNP) located in 53 candidate genes previously reported to have effects on milk production and quality traits in a population of highly selected Holstein-Friesian bulls. A total of 423 semen samples were used to genotype the bulls through a custom oligo pool assay. Forty-five SNP in 32 genes were found to be associated with at least 1 of the tested traits. Most significant and favorable SNP trait associations were observed for polymorphisms located in CCL3 and AGPAT6 genes for fat yield (0.037 and 0.033 $\mathrm{kg} / \mathrm{d}$, respectively), $D G K G$ gene for milk yield (0.698 $\mathrm{kg} / \mathrm{d}), P P A R G C 1 A, C S N 1 S 1$, and AGPAT6 genes for fat percentage $(0.127,0.113$, and $0.093 \%$, respectively), GHR gene for protein $(0.064 \%)$ and casein percentage $(0.053 \%)$, and TLR 4 gene for fat $(0.090 \%)$, protein $(0.066 \%)$, and casein percentage $(0.050 \%)$. Somatic cell score was favorably affected by GHR (-0.095) and POU1F1 (-0.137), and interesting SNP-trait associations were observed for polymorphisms located in CSN2, POU1F1, and AGPAT6 genes for rennet coagulation time $(-0.592,-0.558$, and $-0.462 \mathrm{~min}$, respectively), and GHR and CSN2 genes for curd firmness 30 min after rennet addition $(1.264$ and $1.183 \mathrm{~mm}$, respectively). In addition to the influence of individual SNP, the effects of composite genotypes constructed by grouping SNP according to their individual effects on traits considered in the analysis were also examined. Favorable and significant effects on milk traits were ob-

Received January 31, 2017.

Accepted May 25, 2017.

${ }^{1}$ Corresponding author: martino.cassandro@unipd.it served for 2 composite genotypes, one including 10 SNP and the other 4 SNP. The former was associated with an increase of milk $(0.075 \mathrm{~kg} / \mathrm{d})$, fat $(0.097 \mathrm{~kg} / \mathrm{d})$, protein $(0.083 \mathrm{~kg} / \mathrm{d})$, and casein yields $(0.065 \mathrm{~kg} / \mathrm{d})$, and the latter was associated with an increase of fat $(0.244 \%)$, protein $(0.071 \%)$, and casein percentage $(0.047 \%)$. Although further research is required to validate the identified SNP loci in other populations and breeds, our results can be considered as a preliminary foundation for further replication studies on gene-assisted selection programs.

Key words: candidate gene, milk coagulation trait, milk yield and composition, somatic cell count, Holstein bulls

\section{INTRODUCTION}

In recent decades, interest has been growing in the global quality and technological aspects of livestock products. In the dairy industry, contemporary breeding goals have broadened to include, along with milk production characteristics, health and functional traits in an effort to improve the overall functionality of the dairy cow. In many milk-producing countries, a large fraction of the milk is used for cheesemaking. In Italy, for example, more than $70 \%$ of the overall milk production is used to manufacture cheese; thus, milk technological traits are of great importance for the national dairy industry (Cassandro et al., 2008; Tiezzi et al., 2013). Important milk traits, which include milk yield, composition (fat, protein, and casein content), and milk coagulation properties (MCP), mainly described by rennet coagulation time (RCT; min) and curd firmness 30 min after rennet addition to milk $\left(\mathbf{a}_{\mathbf{3 0}} ; \mathbf{m m}\right)$, have therefore gained considerable interest worldwide. Milk coagulation properties have been reported to improve the efficiency of the cheesemaking process; in fact, milk with a high capacity to properly react to rennet and to produce a firm curd results in greater cheese yield (Bynum and Olson, 1982; Riddell-Lawrence and Hicks, 1989). Pretto et al. (2013) demonstrated that $\mathrm{a}_{30}$ has a positive effect on Grana Padano cheese yield, which 
in turn is expected to result in greater income for the dairy industry. The economic relevance of MCP has been recently reported by Cassandro et al. (2016), who estimated the economic values for RCT and $\mathrm{a}_{30}$ of milk destined to produce Grana Padano cheese in the Italian Holstein cattle population. Moreover, indirect selection for resistance to mastitis through the reduction of SCC is another important goal to be considered for improving milk production and quality.

Exploitable additive genetic variation for milk coagulation ability has been assessed in several cattle breeds in various countries. Heritability estimates of MCP are greater compared with milk yield and similar to other quality traits, ranging from 15 to $40 \%$ (Lindström et al., 1984; Ikonen et al., 2004; Penasa et al., 2010; Vallas et al., 2012). Moreover, the assessment of MCP can be routinely performed through mid-infrared spectroscopy, a technology widely used in milk recording programs to predict milk quality traits (Dal Zotto et al., 2008; De Marchi et al., 2008).

Traditionally, selection to improve profitability of livestock production has been based on EBV calculated from phenotypic records and pedigree, and on knowledge of the heritability of each trait (Goddard and Hayes, 2009). Nevertheless, several authors demonstrated the feasibility of improving cheesemaking-related traits through the identification of QTL affecting the traits (Ogorevc et al., 2009; Meredith et al., 2012; Cecchinato et al., 2014, 2015).

In recent years, due to their abundance and variability, SNP have been largely used in dairy cattle as powerful markers to identify loci underlying phenotypic variation in association studies. The candidate gene strategy allows focusing the analysis on particular genes involved in key metabolic pathways or physiological processes, which are probable to be involved in the traits of interest. The availability of many thousands of SNP has led to the development of genomic selection (Meuwissen et al., 2001). The advantage of this approach over traditional selection is that animals can be selected accurately early in life, based on their genomic predictions, and for traits that are difficult or expensive to measure. Currently, genomic selection is widely used in several countries, especially in the Holstein breed. Costs for analysis of high-density SNP genotyping have decreased dramatically in recent years, but they are still prohibitively high for expanding the analysis to the population level. The selection of a panel of few associated genes for a specific trait can be a viable strategy to reduce the cost of analysis for preselection and within-family selection of young bulls, especially for new traits for which national genetic evaluation is not yet performed, such as MCP. The objective of the present study was to evaluate the effect of 96 SNP and 3 composite genotypes within 53 candidate genes on milk production and composition traits, SCS, and MCP in Italian Holstein-Friesian sires.

\section{MATERIALS AND METHODS}

\section{Sampling and Analysis of Milk Quality}

From October 2011 to September 2014, a total of 292,007 individual milk samples from 45,115 HolsteinFriesian cows reared in Veneto Region (northeast Italy) and daughters of 4,531 sires, were collected during monthly test-day milk recording. Milk samples were collected according to the International Committee for Animal Recording (ICAR, 2009) guidelines and analyzed in the laboratory of the Breeders Association of Veneto region (Padova, Italy) using Milko-Scan FT6000 (Foss Electric A/S, Hillerød, Denmark). Traits recorded were fat $(\mathbf{F P})$, protein $(\mathbf{P P})$, and casein $(\mathbf{C P})$ percentages, RCT, and $\mathrm{a}_{30}$. Mid-infrared spectroscopy models were implemented for routine prediction of MCP, as reported by De Marchi et al. (2013). In addition to quality traits and MCP, information on daily yields $(\mathrm{kg} / \mathrm{d})$ of milk $(\mathbf{M Y})$, fat $(\mathbf{F Y})$, protein $(\mathbf{P Y})$, and casein $(\mathbf{C Y})$ were available. Casein-to-protein $(\mathbf{C} / \mathbf{P} ; \%)$ and protein-to-fat $(\mathbf{P} / \mathbf{F} ; \%)$ ratios were also calculated. Values of SCC were determined with Cell Fossomatic 250 (Foss Electric A/S) and transformed to SCS to achieve normality and homogeneity of variances according to the formula of Wiggans and Shook (1987): $\mathrm{SCS}=3+\log _{2}(\mathrm{SCC} / 100,000)$.

\section{Sires DNA Extraction and Genotyping}

Semen samples were collected from 423 sires and DNA extraction was carried out using the DNeasy Blood \& Tissue Kit (catalog no. 69506, Qiagen, Valencia, CA), following the manufacturer's instructions. The extracted DNA was quantified with the Qubit System (Invitrogen, Carlsbad, CA) and assessed for integrity by $1 \%$ agarose gel electrophoresis.

Candidate gene selection was carried out using both a functional approach and a positional approach. In the functional approach, candidate genes were chosen on the basis of evidence of physiological or biochemical processes related to milk production and quality traits and involved in the immune system. For the positional approach, the identification of candidate genes was mainly based on the physical linkage information in chromosomal regions associated with milk composition and technological properties.

A first panel of 96 SNP was selected within 53 genes using either information available in the literature or in silico, after a database interrogation on NCBI dbSNP 
(https://www.ncbi.nlm.nih.gov/projects/SNP/). All samples were genotyped with the Illumina GoldenGate Assay (Illumina Inc., San Diego, CA) using a 96-SNP custom oligo pool assay. Automatic allele calling was carried out using the GeneCall software (Illumina) with a GCscore threshold of 0.25 . The GCscore is a quality measures on the genotype calls from the genotyping assay.

\section{Statistical Analysis}

Step 1: Estimation and Deregression of Breeding Values. Breeding values were estimated using the following linear animal model:

$$
\mathbf{y}=\mathbf{X} \mathbf{b}+\mathbf{Z}_{\mathbf{h}} \mathbf{h}+\mathbf{Z}_{\mathbf{p}} \mathbf{p}+\mathbf{Z}_{\mathbf{a}} \mathbf{a}+\mathbf{e}
$$

where $\mathbf{y}$ is the vector of phenotypic records for the analyzed traits (MY, FY, PY, CY, FP, PP, CP, SCS, RCT, $\mathrm{a}_{30}, \mathrm{C} / \mathrm{P}$, and $\left.\mathrm{P} / \mathrm{F}\right)$; $\mathbf{b}$ is the vector of fixed effects of parity (3 classes: parity 1, 2, and 3-9) and stage of lactation (12 monthly classes: 6-35, 36-65, 66-95, 96125, 126-155, 156-185, 186-215, 216-245, 246-275, 276-305, 306-335, and 336-365 d); $\mathbf{h}$ is the vector of solutions for herd-test-date random effect $\mathrm{h} \sim N\left(0, \mathbf{I} \sigma_{\mathrm{h}}^{2}\right)$; $\mathbf{p}$ is the vector of solutions for cow permanent environmental effect $\mathrm{p} \sim N\left(0, \mathbf{I} \sigma_{\mathrm{p}}^{2}\right)$; $\mathbf{a}$ is the vector of solutions for animal additive genetic effect a $\sim N\left(0, \mathbf{A} \sigma_{\mathrm{a}}^{2}\right)$; and $\mathbf{e}$ is the vector of random residuals e $\sim N\left(0, \mathbf{I} \sigma_{\mathrm{e}}^{2}\right) . \mathbf{X}, \mathbf{Z}_{\mathrm{h}}, \mathbf{Z}_{\mathrm{p}}$, and $\mathbf{Z}_{\mathrm{a}}$ represent the corresponding incidence matrices linking the phenotypic records to the appropriate random effects, I is an identity matrix of appropriate order, and $\mathbf{A}$ is the additive genetic relationship matrix among individuals. Variance components $\sigma_{\mathrm{h}}^{2}, \sigma_{\mathrm{p}}^{2}, \sigma_{\mathrm{a}}^{2}$, and $\sigma_{\mathrm{e}}^{2}$ were from Tiezzi et al. (2013), and EBV and their standard errors were estimated using the BLUPF90 program (Misztal et al., 2002).

As bull EBV includes pedigree information, there is a risk that SNP could result associated with the trait due to the parental information rather than phenotype. To eliminate the contribution of information from relatives, EBV were deregressed according to Garrick et al. (2009) methodology. The deregressed EBV were used as phenotypic records for the bulls, as their use is proven to be reliable when different number of progeny per bull is available (Garrick et al., 2009).

Step 2: Single-Marker Association Analysis. The SNP that fulfilled the following criteria were included in the association analysis: (1) call rate $\geq 95 \%$, (2) minor allele frequency (MAF) $\geq 5 \%$, and (3) no extreme deviation from Hardy-Weinberg equilibrium $(P$
$>0.001)$. After the quality control, $96 \mathrm{SNP}$, distributed across 43 genes, were retained. Names of genes, their chromosome position referring to Bos taurus UMD_3.1 (http://www.ensembl.org/index.html) assembly, and information about each SNP are given in Table 1. The single-marker regression model was

$$
\mathbf{y}=\mathbf{X b}^{\mathrm{m}}+\mathbf{Z}_{\mathrm{a}} \mathrm{a}+\frac{\mathbf{e}}{\mathbf{w}}
$$

where $\mathbf{y}$ is the vector of pseudo-phenotypes; $b^{m}$ are the mean and mth marker fixed effect solutions; $a$ is the individual additive genetic effect a $\sim N\left(0, \mathbf{A} \sigma_{\mathrm{a}}^{2}\right)$; $\mathbf{e}$ is the vector of residuals $\mathrm{e} \sim N\left(0, \mathbf{I} \sigma_{\mathrm{e}}^{2}\right)$; $\mathbf{w}$ is the vector of weights for the pseudo-phenotypes; $\mathbf{X}$ is the 2-columns incidence matrix reporting a vector of $1 \mathrm{~s}$ (mean) and the number of copies of the minor allele $(0,1$, or 2$)$ for the mth marker over the individuals; and $\mathbf{Z}$ is the incidence matrix for the animal effect. Variance components $\sigma_{a}^{2}$ and $\sigma_{e}^{2}$ were estimated for each trait by marker model, and $\mathbf{I}$ and $\mathbf{A}$ are defined as in step 1 . The model provides an estimate of the regression coefficient of the pseudo-phenotype on the number of copies of the minor allele that is to be interpreted as the average allele substitution effect (i.e., the average change in phenotype when 1 copy of the major allele is substituted with a copy of the minor allele). Individual records were weighted by the reliability of the respective deregressed breeding value. A total of 780 models were run (65 markers by 12 traits). Association analyses were run using the BGLR R-package (Pérez and de Los Campos, 2014).

Step 3: Composite Genotype Association Analysis. Composite genotypes were constructed by grouping SNP according to their individual effects on traits considered in the present study. Using relevant SNP, a total of 3 groups were defined as reported in Table 2. Group 1 included 4 SNP with significant effects for 6 or more different milk traits; group 2 included 10 SNP with significant effects for 5 or more different milk traits; and group 3 included 4 SNP with significant positive effects for only MY. Within each group, only composite genotypes showing a frequency of at least 10 were selected for testing. Composite genotypes were named by collapsing the number of copies of the minor allele for the SNP included in the group (e.g., genotype AA-Bb-Cc-dd would be shown as 0.1.1.2). Composite genotypes belonging to the same group were tested in the same model as

$$
\mathbf{y}=\mathbf{X} \mathbf{b}^{\mathbf{c}}+\mathbf{Z}_{\mathrm{a}} \mathrm{a}+\frac{\mathbf{e}}{\mathbf{w}},
$$


Table 1. List of the successfully genotyped SNP including chromosome (Chr) position referring to Bos taurus UMD_3.1 (http://www.ensembl. org/index.html) and minor allele frequency (MAF)

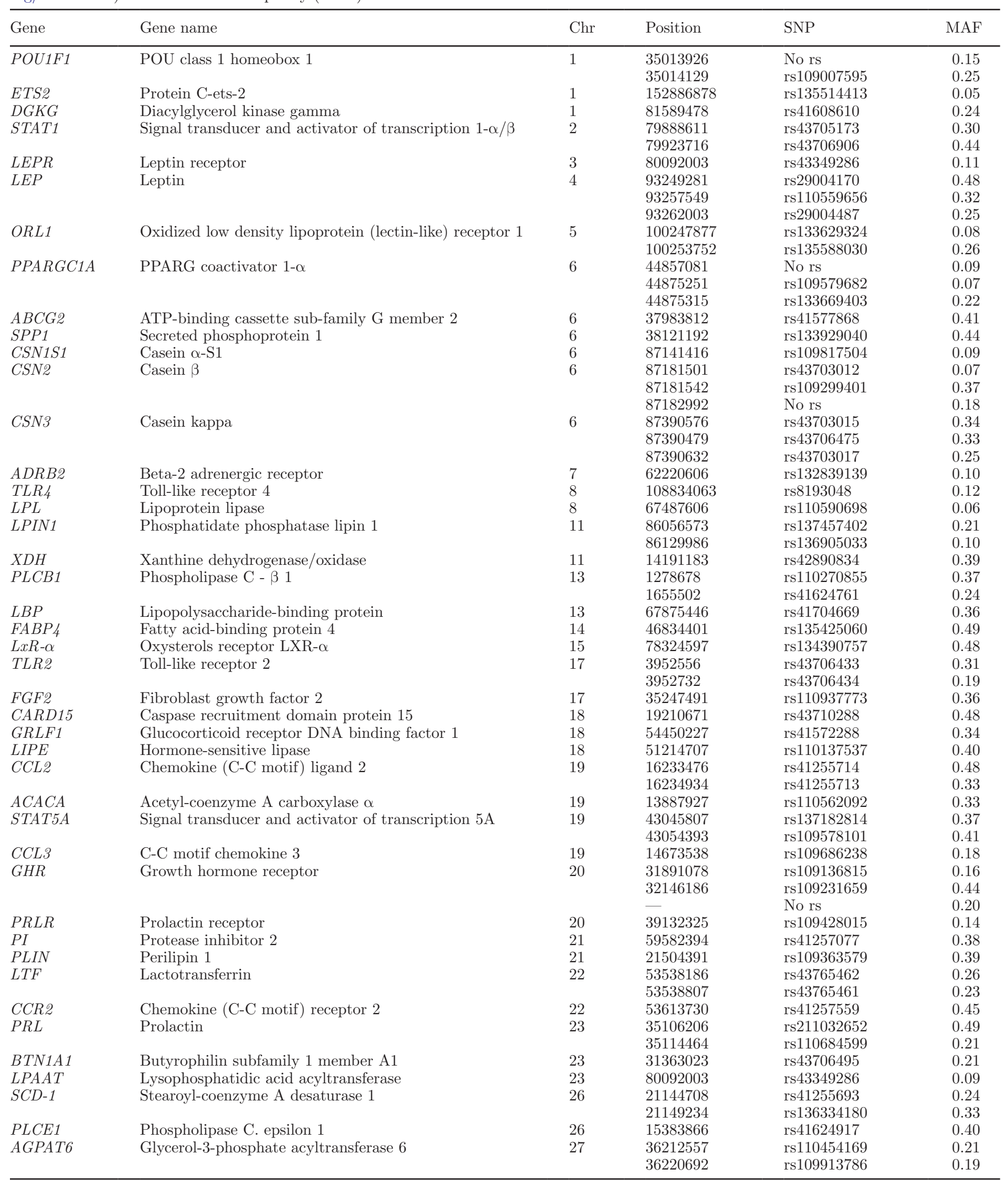


Table 2. List of SNP (dbSNP within parentheses) used for the construction of composite genotypes for 3 groups

\begin{tabular}{lll}
\hline Group $1^{1}$ & Group $2^{2}$ & Group $3^{3}$ \\
\hline PPARGC1A (rs133669403) & DGKG (rs41608610) & DGKG (rs41608610) \\
CSN1S1 (rs110981354) & PPARGC1A (rs133669403) & STAT1 (rs43705173) \\
CSN3 (rs43703015) & CSN1S1 (rs110981354) & CSN2 (rs43703013) \\
GHR (rs41923484) & CSN2 (rs109299401) & \\
& CSN2 (rs43703013) & \\
& CSN3 (rs43703015) & \\
GHR (rs41923484) & \\
& AGPAT6 (rs1099137876) & \\
& STAT5A (rs109578101) & \\
LPL (rs110590698) & \\
${ }^{1}$ Group of SNP with significant effects on 6 or more traits. & \\
${ }^{2}$ Group of SNP with significant effects on 5 or more traits. & \\
${ }^{3}$ Group of SNP with significant positive effects on milk yield. &
\end{tabular}

where $\mathbf{y}, \mathrm{a}, \mathbf{e}, \mathbf{w}$, and $\mathbf{Z}_{\mathrm{a}}$ are defined as above; and $\mathbf{X}$ and $\mathbf{b}^{\mathbf{c}}$ are the incidence matrix and vector of solutions for the mean and the composite genotypes, respectively, used to test for each group as presented in Table 2. Variance components $\sigma_{a}^{2}$ and $\sigma_{e}^{2}$ were estimated for each trait by group model. A total of 36 models were run (3 groups by 12 traits).

\section{RESULTS AND DISCUSSION}

\section{Descriptive Statistics}

Descriptive statistics and additive genetic variance used for breeding value estimation of the investigated traits are provided in Table 3. Milk yield, FY, PY, and CY averaged 29.81, 1.12, 1.00, and $0.78 \mathrm{~kg} / \mathrm{d}$, respectively, which are slightly lower than findings of previous studies on the same dairy cattle breed (Cassandro et al., 2008; Tiezzi et al., 2013). Means of FP, PP, and

Table 3. Descriptive statistics of milk production and composition traits, SCS, and milk technological traits, and estimates of additive genetic variance $\left(\sigma_{\mathrm{a}}{ }^{2}\right)$ used for breeding value estimation

\begin{tabular}{lrrr}
\hline Trait & Mean & SD & \multicolumn{1}{c}{$\sigma_{\mathrm{a}}{ }^{2}$} \\
\hline Milk production, kg/d & & & \\
$\quad$ Milk yield & 29.81 & 9.42 & 7.0907 \\
Fat yield & 1.12 & 0.36 & 0.0089 \\
Protein yield & 1.00 & 0.28 & 0.0063 \\
$\quad$ Casein yield & 0.78 & 0.22 & 0.0041 \\
Milk composition, \% & & & \\
Fat & 3.83 & 0.78 & 0.0944 \\
Protein & 3.42 & 0.42 & 0.0256 \\
Casein & 2.68 & 0.35 & 0.0179 \\
SCS & 3.05 & 1.88 & 0.3076 \\
Milk technological trait ${ }^{1}$ & & & \\
$\quad$ RCT, min & 22.22 & 19.09 & 2.8863 \\
a mm & 23.49 & 5.44 & 17.6962 \\
Casein/protein, \% & 78.27 & 10.30 & 0.2754 \\
Protein/fat, \% & 92.30 & 2.03 & 35.5581 \\
\hline${ }^{1}$ RCT = rennet coagulation time; $\mathrm{a}_{30}=$ curd firmness at 30 min after \\
rennet addition.
\end{tabular}

CP were $3.83,3.42$, and $2.68 \%$, respectively, in agreement with values reported for the Holstein-Friesian cow (Cassandro et al., 2008; Tiezzi et al., 2013). The average SCS was 3.05, which is in the physiological range and in line with the value (3.08) reported by Cassandro et al. (2008). Regarding MCP, RCT occurred at 22.22 min and $\mathrm{a}_{30}$ was $23.49 \mathrm{~mm}$. Rennet coagulation time was slightly longer than values reported in previous studies, which ranged from 20.2 to $20.7 \mathrm{~min}$ (Tiezzi et al., 2013; Penasa et al., 2014; Cassandro et al., 2015). The average of $\mathrm{a}_{30}$ was similar to results reported by Penasa et al. (2014) and Cassandro et al. (2015), but greater than $\mathrm{a}_{30}(21.71 \mathrm{~mm})$ of Tiezzi et al. (2013). Possible differences between the current and previous studies for MCP include sampling size and time as well as breed and parity of the cow.

\section{Allele Frequencies}

Of the 96 selected SNP, a total of 65 SNP in 43 candidate genes located on 21 chromosomes were successfully genotyped in 423 sires. The MAF ranged from 0.05 to 0.49 . Thirty SNP had minor allele frequencies between 0.31 and $0.49,24$ between 0.12 and 0.30 , and 11 lower than 0.12 (Table 1). For the other remaining SNP excluded from the analysis, 12 SNP failed in the genotyping process (insufficient intensity for cluster separation or poor cluster definition), 15 SNP had MAF $<5 \%$ and 4 SNP were genotyped for a lower sample size (number of bulls <423; Supplemental Table S1, https://doi.org/10.3168/jds.2017-12666).

\section{Single-Marker Association Analysis}

Through the use of deregressed EBV it was possible to estimate the association between SNP and phenotypic traits. A total of $45 \mathrm{SNP}$, located in 32 candidate genes, were significantly associated $(P<0.05)$ or exhib- 
ited a statistical trend for association $(P<0.10)$ with at least 1 of the milk traits investigated (Table 4 ), indicating putative pleiotropic effects and confirming the positive or negative genetic correlation between traits. Significant SNP were spotted on 18 chromosomes, with 11 SNP (24.4\%) identified on BTA chromosome 6. Of the 32 candidate genes identified, 23 were found in association with several traits, whereas the remaining 9 had effects only on 1 trait. Most relevant SNP milk trait associations were observed for $C C L 3, A G P A T 6$, $D G K G$, and $C S N 3$ with milk yield traits; PPARGC1A, AGPAT6, CSN1S1, GHR, TLR4, LPL, and DGKG with milk composition traits; and GHR with SCS. Interesting genes associated with MCP were CSN2, CSN3, POU1F1, GHR, and AGPAT6.

Milk Yield Traits. Considering milk yield traits (MY, FY, PY, and CY), we identified significant associations for $13 \mathrm{SNP}$ in 12 genes $(P<0.05$; Table 4). Polymorphisms $D G K G$ rs41608610 $(P<0.01)$, STAT1 rs43705173, and CSN2 rs43703013 $(P<0.05)$ resulted in an increase of MY ranging from 0.473 to $0.698 \mathrm{~kg} / \mathrm{d}$, whereas PPARGC1A rs133669403 (-0.693 $\mathrm{kg} / \mathrm{d} ; P<0.05)$ and TLR 4 rs8193066 $(-0.669 \mathrm{~kg} / \mathrm{d} ; P$ $<0.05)$ negatively affected this trait. Polymorphisms associated with FY increment were CCL3 rs109686238 $(0.037 \mathrm{~kg} / \mathrm{d} ; P<0.001), A G P A T 6$ rs109913786 (0.033 $\mathrm{kg} / \mathrm{d} ; P<0.01)$, and CSN1S1 rs110981354 (0.026 kg/d; $P<0.05)$, whereas $L P L$ rs110590698 $(-0.037 \mathrm{~kg} / \mathrm{d}$; $P<0.05)$ and $F G F 2$ rs $110937773(-0.018 \mathrm{~kg} / \mathrm{d} ; P<$ $0.05)$, both known to be involved in milk production or fat synthesis (Keso et al., 2001; Wang et al., 2008), were associated with a reduction of daily FY (Table 4). An increase of both PY and CY was reported for CSN2 rs109299401 (0.027 and $0.023 \mathrm{~kg} / \mathrm{d}$, respectively; $P<0.05)$ and $G H R$ rs41923484 $(0.017$ and $0.014 \mathrm{~kg} / \mathrm{d}$, respectively; $P<0.05$ ), whereas $C C L 3$ rs109686238 affected only PY $(0.017 \mathrm{~kg} / \mathrm{d} ; P<0.05)$. Genetic variants of the $\beta$-CN gene (CSN2) were associated with greater milk, protein, and casein yields, further confirming a major role of the casein gene cluster in affecting production traits (e.g., Nilsen et al., 2009; Huang et al., 2012; Russo et al., 2012). In contrast, the polymorphism rs43703015 of the bovine $\kappa-\mathrm{CN}$ gene (CSN3), which is associated with higher milk quality (Boettcher et al., 2004; Caroli et al., 2009) and FY (Mancini et al., 2013), reduced PY and CY (-0.020 and -0.017 $\mathrm{kg} / \mathrm{d}$, respectively, $P<0.01$; Table 4 ). This result is in line with other studies reporting a decrease of milk yield traits (Kučerová et al., 2006) or no significant association for polymorphisms in the CSN3 region and milk traits in different cattle breeds (Cecchinato et al., 2014; Fontanesi et al., 2015; Rahmatalla et al., 2015).

Milk Composition Traits. Several genetic factors influence the composition of milk. Here we observed significant association for at least 1 of the milk composition traits (FP, PP, and CP) for 20 SNP located in 17 genes $(P<0.05$; Table 4$)$. The polymorphism rs 133669403 , located in the PPARGC1A gene, was associated with an increase of FP $(0.127 \% ; P<0.001)$. This was in contrast to SNP association results previously reported for the German Holstein population (Weikard et al., 2005), in which an increment of milk FY but a reduction of FP were observed, indicating that the PPARGC1A gene might be involved in genetic variation underlying the QTL for milk fat synthesis on BTA6. Significant associations with FP were also found in $D G K G$ rs41608610 $(-0.108 \% ; P<0.001)$ and $L P L$ rs110590698 (-0.148\%; $P<0.001)$, which decreased milk FP (Table 4). Moreover, a significant positive influence on FP was reported for polymorphisms CSN1S1 rs110981354, TLR4 rs8193066, and AGPAT6 rs109913786, with estimated effects ranging from 0.090 to $0.113 \%(P<0.01)$, and for $O R L 1$ rs135588030, GHR rs41923484, LTF rs43765462, and PLCE1 rs41624917 from 0.050 to $0.064 \%(P<0.05)$.

Considering polymorphisms of the casein genes, known to be relevant in relation to milk production traits and milk protein quality, the variants rs109299401 and rs43703011 of the CSN2 gene increased PP by 0.056 and $0.033 \%$ and FP by 0.050 and $0.027 \%$, respectively $(P<0.05)$. Opposite effects on those 2 traits were observed for another CSN2 polymorphism (rs43703013), which decreased PP by $0.030 \%$ and FP by $0.023 \%(P<0.05)$. The effect observed in our study for CSN2 rs109299401 on PP was opposite to findings of Fontanesi et al. (2014) in Holstein sires. Moreover, PP was negatively affected $(-0.024 \% ; P<0.05)$ by CSN3 (rs43703017), which is known to affect PP in different dairy populations (Boettcher et al., 2004). However, our result is in line with the moderate to negligible effect of this gene on milk composition traits reported in Holstein-Friesian (Penasa et al., 2010) and in Brown Swiss cows (Cecchinato et al., 2014). Finally, SNP CSN1S1 rs110981354 increased PP $(0.046 \% ; P<$ $0.05)$ and $\mathrm{FP}(0.113 \% ; P<0.01)$.

Besides the casein genes, 5 other polymorphisms enhanced milk PP: TLR4 rs8193066 (0.066\%; $P<$ $0.001)$, GHR rs41923484 (0.064\%; $P<0.001)$, and PPARGC1A rs133669403 and rs109579682, and PRLR rs109428015 (0.032-0.044\%; $P<0.05)$. Milk CP was positively affected by TLR 4 rs8193066 $(0.050 \% ; P<$ $0.001)$ and GHR rs41923484 (0.053\%; $P<0.001)$, and by CSN2 rs109299401 and rs43703011, PPARGC1A rs109579682, PRLR rs109428015, LPIN1 rs137457402, and CCL2 rs41255713 $(0.025-0.050 \% ; P<0.05)$. The GHR gene, in particular, is considered a strong candidate gene affecting MY and composition, as it is in close proximity to QTL previously shown to influence 
GENE-ASSISTED SELECTION FOR MILK TRAITS

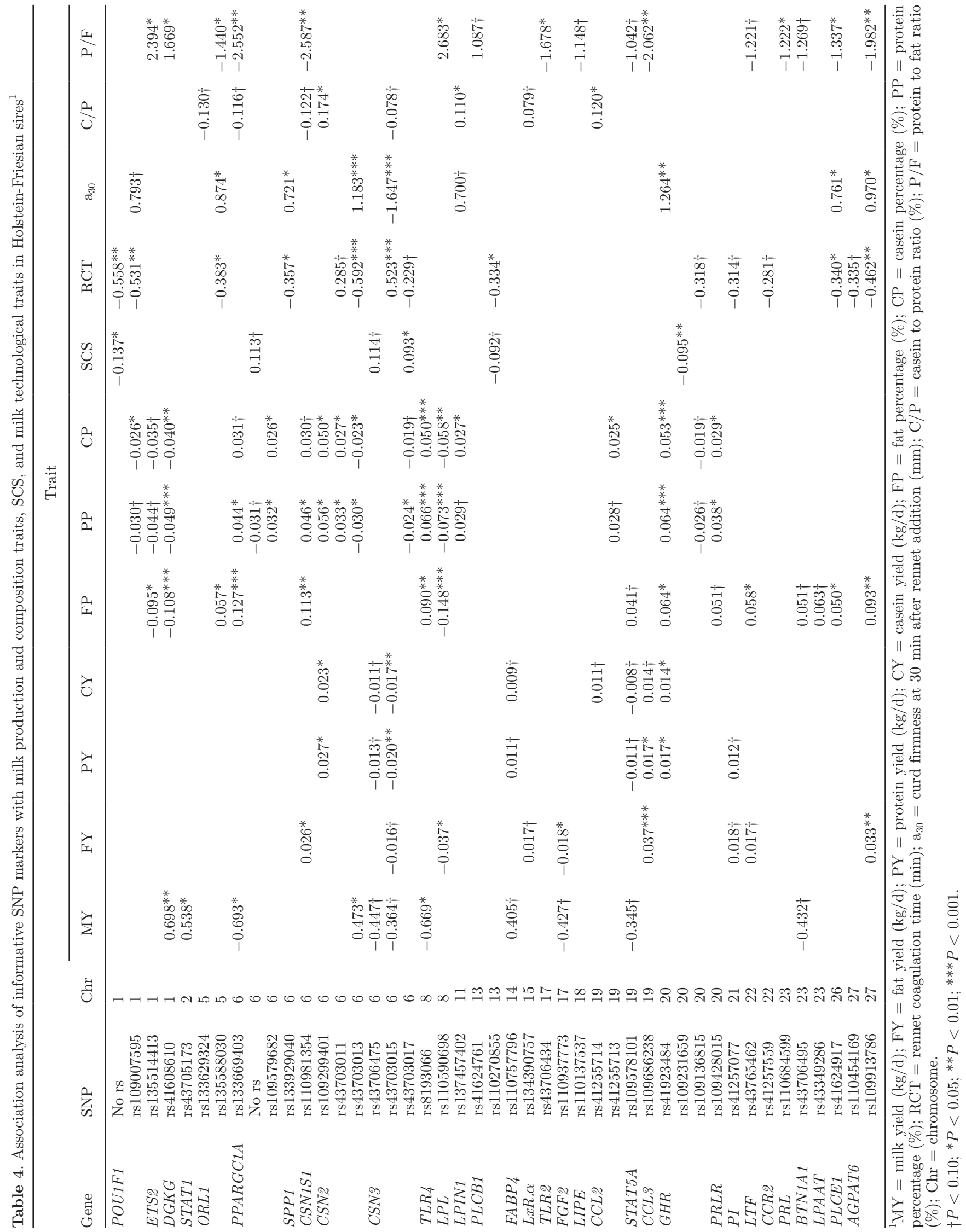


those traits in Holstein dairy breed (Arranz et al., 1998; Blott et al., 2003; Rahmatalla et al., 2011; Waters et al., 2011; Meredith et al., 2012) and Finnish Ayrshire breed (Viitala et al., 2006). According to Cecchinato et al. (2014), LPIN1 rs137457402 affected CP, resulting in an increase of this trait $(0.027 \% ; P<0.05)$. On the contrary, SNP DGKG rs41608610 and $L P L$ rs110590698 were associated with a significant reduction of PP ( -0.049 and $-0.073 \%$, respectively; $P<$ $0.001)$ and $\mathrm{CP}(-0.040$ and $-0.058 \%$, respectively; $P$ $<0.01)$. Interestingly, these $2 \mathrm{SNP}$ were both found to reduce $\mathrm{PP}$ and $\mathrm{CP}$ of Holstein cow milk in the present study, whereas they had no effect on the same traits in Brown Swiss milk (Cecchinato et al., 2014).

SCS. Interesting results were obtained for SNP within the GHR (rs109231659) and POU1F1 (no rs) genes, which determined a reduction of the SCS by 0.095 and 0.137 , respectively $(P<0.05$; Table 4$)$. As reported in other Holstein populations (Gengler et al., 2008; Rahmatalla et al., 2011; Waters et al., 2011), our study confirmed the significant effect of $G H R$ on the reduction of the SCS, which is an interesting candidate for selection to improve resistance against mastitis. Nevertheless, in the Brown Swiss cattle breed investigated by Cecchinato et al. (2014), this polymorphism had no effect on SCS. The SNP rs43703017, located in the $\kappa$-CN gene $(C S N 3)$, was associated with an increase of SCS (0.093, $P<0.05$; Table 4).

Milk Technological Traits. We obtained interesting results for the improvement of MCP for 9 and 8 polymorphisms associated with $\mathrm{RCT}$ and $\mathrm{a}_{30}$, respectively (Table 4). Significant polymorphism associations with MCP were observed in the casein genes, CSN2 and CSN3, according to previous findings (Caroli et al., 2009; Penasa et al., 2010). In particular, in our population, $\beta-C N$ gene polymorphism, CSN2 rs43703013, was associated with shorter RCT $(-0.592 \mathrm{~min} ; P<$ $0.001)$ and greater $\mathrm{a}_{30}(1.183 \mathrm{~mm} ; P<0.001)$, resulting in the increased suitability of milk for processing and cheesemaking (Cassandro et al., 2008). Association with AGPAT6 rs109913786 polymorphism resulted in a better coagulation of milk, with shorter RCT $(-0.462$ min; $P<0.01)$ and greater $\mathrm{a}_{30}(0.970 \mathrm{~mm} ; P<0.05)$. Moreover, favorable associations with both MCP analyzed were found for SNP rs135588030, rs133929040, and rs41624917 located in ORL1, SPP1, and PLCE1, respectively, with an estimated effect for RCT ranging from -0.383 to $-0.340 \mathrm{~min}(P<0.05)$ and for $\mathrm{a}_{30}$ from 0.721 to $0.874 \mathrm{~mm}(P<0.05$; Table 4$)$.

The polymorphism of the $\mathrm{k}-\mathrm{CN}$ gene, CSN3 rs43703015, has shown to negatively affect MCP, as it was associated with longer RCT $(0.523 \mathrm{~min} ; P<$ $0.001)$ and lower $\mathrm{a}_{30}(-1.647 \mathrm{~mm} ; P<0.001)$. The polymorphism POU1F1 rs109007595 improved RCT
$(-0.531 \mathrm{~min} ; P<0.01)$. A positive effect for cheesemaking ability was observed also for SNP POU1F1 (no rs) and $P L C B 1$ rs110270855, which were associated with the reduction of RCT by $0.558 \min (P<0.01)$ and $0.334 \mathrm{~min}(P<0.05)$, respectively. Finally, the polymorphism GHR rs41923484 had a positive effect on $\mathrm{a}_{30}(1.264 \mathrm{~mm} ; P<0.01)$.

Milks with greater $\mathrm{C} / \mathrm{P}$ ratio generally produce firmer curds and lead to less moisture in cheeses; this ratio has been used as an indicator of the suitability of milks for cheesemaking (Auldist et al., 2002). In the present study, the polymorphisms CSN2 rs109299401, LPIN1 rs137457402, and CCL2 rs41255714 increased this trait $(0.110-0.174 \% ; P<0.05)$. Four polymorphisms, namely PPARGC1A rs133669403, CSN1S1 rs110981354, CCL3 rs109686238, and AGPAT6 rs109913786, were significantly associated with a less favorable $\mathrm{P} / \mathrm{F}$ ratio for cheesemaking in our population $(-2.587$ to $-1.982 \% ; P<0.01)$, whereas $D G K G$ rs41608610, ETS2 rs135514413, and LPL rs110590698 were associated with a higher $\mathrm{P} / \mathrm{F}$ ratio $(1.669-2.683 \%$, $P<0.05$; Table 4).

\section{Composite Genotype Association Analysis}

The associations of composite genotypes with milk yield and composition traits, SCS, and milk technological traits are presented in Table 5. Composite genotypes were constructed by grouping SNP in 3 groups according to their individual effects on traits as reported in Table 4. Two, 4, and 6 significant composite genotypes were detected for group 1, group 2, and group 3, respectively.

The composite genotypes 2.1.1.2 of group 1 (MY, $-0.069 \mathrm{~kg} / \mathrm{d} ; \mathrm{FY},-0.086 \mathrm{~kg} / \mathrm{d} ; \mathrm{PY},-0.079 \mathrm{~kg} / \mathrm{d} ; \mathrm{CY}$, $-0.054 \mathrm{~kg} / \mathrm{d}$; Table 5) and 0.2.2.0.0.2.2.2.1.0 of group 2 (MY, $-0.049 \mathrm{~kg} / \mathrm{d} ; \mathrm{FY},-0.060 \mathrm{~kg} / \mathrm{d} ; \mathrm{PY},-0.056$ $\mathrm{kg} / \mathrm{d}$; CY, $-0.038 \mathrm{~kg} / \mathrm{d}$; Table 5) were unfavorably associated with milk yield traits, whereas a positive significant effect on all milk yield traits was observed for the composite genotype 0.2.2.0.0.2.2.1.0.0 of group 2 (MY, $0.075 \mathrm{~kg} / \mathrm{d} ; \mathrm{FY}, 0.097 \mathrm{~kg} / \mathrm{d} ; \mathrm{PY}, 0.083 \mathrm{~kg} / \mathrm{d} ; \mathrm{CY}$, $0.065 \mathrm{~kg} / \mathrm{d}$; Table 5). Milk composition was negatively influenced by 4 composite genotypes of group 2, exerting a reduction of FP $(-0.216$ to $-0.115 \%)$, and by 4 genotypes of group 3, which decreased FP ( -0.188 to $-0.098 \%)$ and CP $(-0.034 \%)$. The only exception was the genotype 0.2 .0 .0 of group 3, which was associated with a positive effect on those traits (FP, $0.244 \%$; PP, $0.071 \%$; CP, $0.047 \%$; Table 5). An increase of SCS was observed for 1 composite genotype of group 1 (0.669) and 2 of group 3 (0.651 and 0.656). The only significant association with MCP was observed for the genotype 0.2.0.1 (group 3), which decreased $\mathrm{a}_{30}(-0.155 \mathrm{~mm}$ ), 
Table 5. Estimated effects and SE of significant composite genotypes on the studied traits

\begin{tabular}{|c|c|c|c|c|c|c|}
\hline Trait $^{1}$ & Gene group & Genotype $^{2}$ & Frequency $^{3}$ & Estimate & $\mathrm{SE}$ & HPD9 $5^{4}$ \\
\hline \multirow{2}{*}{ MY } & Group 2 & 0.2 .2 .0 .0 .2 .2 .2 .1 .0 & 22 & -0.049 & 0.028 & $-0.003 ;-0.096$ \\
\hline & Group 2 & 0.2 .2 .0 .0 .2 .2 .1 .0 .0 & 10 & 0.075 & 0.039 & $0.139 ; 0.011$ \\
\hline \multirow{2}{*}{ FY } & Group 2 & 0.2 .2 .0 .0 .2 .2 .1 .0 .0 & 10 & 0.097 & 0.054 & $0.186 ; 0.009$ \\
\hline & Group 2 & 0.2 .2 .0 .0 .2 .2 .2 .1 .0 & 22 & -0.060 & 0.034 & $-0.004 ;-0.116$ \\
\hline PY & Group 1 & 2.1.1.2 & 14 & -0.079 & 0.041 & $-0.011 ;-0.146$ \\
\hline \multirow{2}{*}{$\mathrm{CY}$} & Group 2 & 0.2 .2 .0 .0 .2 .2 .1 .0 .0 & 10 & 0.065 & 0.034 & $0.122 ; 0.009$ \\
\hline & Group 2 & 0.2 .2 .0 .0 .2 .2 .2 .1 .0 & 22 & -0.038 & 0.023 & $-0.001 ;-0.075$ \\
\hline \multirow{4}{*}{ FP } & Group 2 & 0.2 .2 .0 .0 .2 .2 .1 .0 .0 & 10 & -0.175 & 0.100 & $-0.011 ;-0.339$ \\
\hline & Group 2 & 0.2 .2 .0 .0 .2 .2 .2 .0 .0 & 11 & -0.216 & 0.088 & $-0.071 ;-0.362$ \\
\hline & Group 2 & 0.2 .2 .0 .0 .2 .2 .2 .1 .0 & 22 & -0.115 & 0.069 & $-0.001 ;-0.229$ \\
\hline & Group 2 & 1.2.2.0.1.1.2.2.1.0 & 17 & -0.171 & 0.075 & $-0.047 ;-0.294$ \\
\hline $\mathrm{PP}$ & Group 3 & 0.2 .0 .0 & 16 & 0.071 & 0.034 & $0.127 ; 0.014$ \\
\hline \multirow[t]{2}{*}{$\mathrm{CP}$} & Group 3 & 0.2 .0 .0 & 16 & 0.047 & 0.029 & $0.094 ; 0.000$ \\
\hline & Group 3 & 0.2 .0 .1 & 47 & -0.034 & 0.019 & $-0.004 ;-0.065$ \\
\hline \multirow[t]{3}{*}{ SCS } & Group 1 & 2.2 .0 .2 & 20 & 0.669 & 0.298 & $1.160 ; 0.179$ \\
\hline & Group 3 & 0.1 .0 .0 & 22 & 0.651 & 0.279 & $1.110 ; 0.192$ \\
\hline & Group 3 & 0.2 .0 .2 & 17 & 0.656 & 0.339 & $1.213 ; 0.098$ \\
\hline $\mathrm{a}_{30}$ & Group 3 & 0.2 .0 .1 & 47 & -0.155 & 0.073 & $-0.035 ;-0.275$ \\
\hline $\mathrm{C} / \mathrm{P}$ & Group 3 & 0.2 .0 .1 & 47 & -0.482 & 0.251 & $-0.069 ;-0.894$ \\
\hline \multirow[t]{6}{*}{$\mathrm{P} / \mathrm{F}$} & Group 2 & 0.2 .2 .0 .0 .2 .2 .1 .0 .0 & 10 & -0.085 & 0.035 & $-0.027 ;-0.143$ \\
\hline & Group 2 & 0.2 .2 .0 .0 .2 .2 .2 .0 .0 & 11 & -0.086 & 0.036 & $-0.027 ;-0.146$ \\
\hline & Group 2 & 0.2 .2 .0 .0 .2 .2 .2 .1 .0 & 22 & -0.061 & 0.024 & $-0.021 ;-0.102$ \\
\hline & Group 2 & 1.2 .2 .0 .1 .1 .2 .2 .1 .0 & 17 & -0.057 & 0.028 & $-0.011 ;-0.102$ \\
\hline & Group 3 & 0.1 .0 .0 & 22 & -0.077 & 0.027 & $-0.033 ;-0.121$ \\
\hline & Group 3 & 0.2 .0 .0 & 16 & 0.054 & 0.030 & $0.103 ; 0.005$ \\
\hline
\end{tabular}

${ }^{1} \mathrm{MY}=$ milk yield $(\mathrm{kg} / \mathrm{d}) ; \mathrm{FY}=$ fat yield $(\mathrm{kg} / \mathrm{d}) ; \mathrm{PY}=$ protein yield $(\mathrm{kg} / \mathrm{d}) ; \mathrm{CY}=$ casein yield $(\mathrm{kg} / \mathrm{d}) ; \mathrm{FP}=$ fat percentage $(\%) ; \mathrm{PP}=$ protein percentage $(\%) ; \mathrm{CP}=$ casein percentage $(\%) ; \mathrm{RCT}=$ rennet coagulation time $(\mathrm{min}) ; \mathrm{a}_{30}=$ curd firmness at 30 min after rennet addition $(\mathrm{mm}) ;$ $\mathrm{C} / \mathrm{P}=$ casein to protein ratio $(\%) ; \mathrm{P} / \mathrm{F}=$ protein to fat ratio $(\%)$.

${ }^{2}$ Composite genotypes were named as collapsing the number of copies of the minor allele for the SNP included in the group (e.g., genotype AA$\mathrm{Bb}-\mathrm{Cc}$-dd would be shown as 0.1.1.2). SNP included in composite genotypes are arranged according to the order reported in Table 2 for each group.

${ }^{3}$ Frequency is the number of bulls exhibiting that composite genotype.

${ }^{4} \mathrm{HPD} 95=$ lower and upper bound of the $95 \%$ highest posterior density region.

resulting in the worsening of milk clotting characteristics. Composite genotypes had negative effects on $\mathrm{P} / \mathrm{F}(-0.086$ to $-0.057 \%)$ and $\mathrm{C} / \mathrm{P}(-0.482 \%)$ ratios, except for genotype 0.2.0.1 for $\mathrm{P} / \mathrm{F}$ (0.054\%; Table 5).

\section{CONCLUSIONS}

The present research is the first study carried out in the Italian Holstein-Friesian breed with the aim of identifying genomic regions putatively associated with milk technological traits. Forty-five SNP in 32 genes were associated with at least 1 of the analyzed traits (milk production and composition, SCS, and MCP). In particular, favorable associations with MCP were observed for CSN2, POU1F1, GHR, AGPAT6, ORL1,
SPP1, PLCB1, and PLCE1. Other genes did positively associate with milk yield traits (CCL3, AGPAT6, DGKG, STAT1, CSN1S1, CSN2, GHR), composition traits (PPARGC1A, AGPAT6, CSN1S1, GHR, TLR4, ORL1, CSN2, CCL2, PRLR, LTF, PLCE1), and SCS (GHR and POU1F1). In addition, favorable effects on milk traits were observed for 2 composite genotypes: 1 genotype (0.2.2.0.0.2.2.1.0.0) of group 2 exerted an increment of milk yield traits and 1 genotype (0.2.0.0) of group 3 was associated with higher milk composition. Information on composite genotypes may be useful in preselection of young bulls for several traits, including MCP. Although further experimentation is required to validate the identified SNP loci in other populations and breeds, results of the present study can be con- 
sidered as a preliminary foundation for future research on gene-assisted selection programs in the HolsteinFriesian breed.

\section{ACKNOWLEDGMENTS}

This research was supported by a grant from the University of Padova (Italy), code no. CPDR140215/14: "Assessing the genomic architecture of milk technological traits in Italian Holstein-Friesian cattle breed." The authors acknowledge Intermizoo Spa (Padova, Italy) for providing bovine semen samples used in the study, and the Italian Holstein Association (ANAFI, Cremona, Italy) for pedigree information.

\section{REFERENCES}

Arranz, J.-J., W. Coppieters, P. Berzi, N. Cambisano, B. Grisart, L. Karim, F. Marcq, L. Moreau, C. Mezer, J. Riquet, P. Simon, P. Vanmanshoven, D. Wagenaar, and M. Georges. 1998. A QTL affecting milk yield and composition maps to bovine chromosome 20: a confirmation. Anim. Genet. 29:107-115.

Auldist, M., C. Mullins, B. O'Brien, B. T. O'Kennedy, and T. Guinee. 2002. Effect of cow breed on milk coagulation properties. Milchwissenschaft 57:140-143.

Blott, S., J.-J. Kim, S. Moisio, A. Schmidt-Küntzel, A. Cornet, P. Berzi, N. Cambisano, C. Ford, B. Grisart, D. Johnson, L. Karim, P. Simon, R. Snell, R. Spelman, J. Wong, J. Vilkki, M. Georges, F. Farnir, and W. Coppieters. 2003. Molecular dissection of a quantitative trait locus: a phenylalanine-to-tyrosine substitution in the transmembrane domain of the bovine growth hormone receptor is associated with a major effect on milk yield and composition. Genetics 163:253-266.

Boettcher, P. J., A. Caroli, A. Stella, S. Chessa, E. Budelli, F. Canavesi, S. Ghiroldi, and G. Pagnacco. 2004. Effects of casein haplotypes on milk production traits in Italian Holstein and Brown Swiss cattle. J. Dairy Sci. 87:4311-4317.

Bynum, D. G., and N. F. Olson. 1982. Influence of curd firmness at cutting on yield and recovery of milk constituents. J. Dairy Sci. 65:2281-2290.

Caroli, A. M., S. Chessa, and G. J. Erhardt. 2009. Invited review: Milk protein polymorphisms in cattle: Effect on animal breeding and human nutrition. J. Dairy Sci. 92:5335-5352.

Cassandro, M., M. Battagin, M. Penasa, and M. De Marchi. 2015. Short communication: Genetic relationships of milk coagulation properties with body condition score and linear type traits in Holstein-Friesian cows. J. Dairy Sci. 98:685-691.

Cassandro, M., A. Comin, M. Ojala, R. Dal Zotto, M. De Marchi, L. Gallo, P. Carnier, and G. Bittante. 2008. Genetic parameters of milk coagulation properties and their relationships with milk yield and quality traits in Italian Holstein cows. J. Dairy Sci. 91:371376.

Cassandro, M., D. Pretto, N. Lopez-Villalobos, M. De Marchi, and M. Penasa. 2016. Estimation of economic values for milk coagulation properties in Italian Holstein-Friesian cattle. J. Dairy Sci. 99:6619-6626.

Cecchinato, A., S. Chessa, C. Ribeca, C. Cipolat-Gotet, T. Bobbo, J. Casellas, and G. Bittante. 2015. Genetic variation and effects of candidate-gene polymorphisms on coagulation properties, curd firmness modeling and acidity in milk from Brown Swiss cows. Animal 9:1104-1112.

Cecchinato, A., C. Ribeca, S. Chessa, C. Cipolat-Gotet, F. Maretto, J. Casellas, and G. Bittante. 2014. Candidate gene association analysis for milk yield, composition, urea nitrogen and somatic cell scores in Brown Swiss cows. Animal 8:1062-1070.
Dal Zotto, R., M. De Marchi, A. Cecchinato, M. Penasa, M. Cassandro, P. Carnier, L. Gallo, and G. Bittante. 2008. Reproducibility and repeatability of measures of milk coagulation properties and predictive ability of mid-infrared reflectance spectroscopy. J. Dairy Sci. 91:4103-4112.

De Marchi, M., G. Bittante, R. Dal Zotto, C. Dalvit, and M. Cassandro. 2008. Effect of Holstein Friesian and Brown Swiss breeds on quality of milk and cheese. J. Dairy Sci. 91:4092-4102.

De Marchi, M., V. Toffanin, M. Cassandro, and M. Penasa. 2013. Prediction of coagulating and noncoagulating milk samples using mid-infrared spectroscopy. J. Dairy Sci. 96:4707-4715.

Fontanesi, L., D. G. Calò, G. Galimberti, R. Negrini, R. Marino, A. Nardone, P. Ajmone-Marsan, and V. Russo. 2014. A candidate gene association study for nine economically important traits in Italian Holstein cattle. Anim. Genet. 45:576-580.

Fontanesi, L., E. Scotti, A. B. Samorè, A. Bagnato, and V. Russo. 2015. Association of 20 candidate gene markers with milk production and composition traits in sires of Reggiana breed, a local dairy cattle population. Livest. Sci. 176:14-21.

Garrick, D. J., J. F. Taylor, and R. L. Fernando. 2009. Deregressing estimated breeding values and weighting information for genomic regression analyses. Genet. Sel. Evol. 41:55.

Gengler, N., S. Abras, C. Verkenne, S. Vanderick, M. Szydlowski, and R. Renaville. 2008. Accuracy of prediction of gene content in large animal populations and its use for candidate gene detection and genetic evaluation. J. Dairy Sci. 91:1652-1659.

Goddard, M. E., and B. J. Hayes. 2009. Mapping genes for complex traits in domestic animals and their use in breeding programmes. Nat. Rev. Genet. 10:381-391.

Huang, W., F. Peñagaricano, K. R. Ahmad, J. A. Lucey, K. A. Weigel, and H. Khatib. 2012. Association between milk protein gene variants and protein composition traits in dairy cattle. J. Dairy Sci. 95:440-449.

ICAR (International Committee for Animal Recording). 2009. International agreement of recording practices. Guidelines Approved by the General Assembly held in Niagara Falls, NY, June 18, 2008. International Committee for Animal Recording, Rome, Italy.

Ikonen, T., S. Morri, A.-M. Tyrisevä, O. Ruottinen, and M. Ojala. 2004. Genetic and phenotypic correlations between milk coagulation properties, milk production traits, somatic cell count, casein content, and pH of milk. J. Dairy Sci. 87:458-467.

Keso, T., M. Perola, P. Laippala, E. Ilveskoski, T. A. Kunnas, J. Mikkelsson, A. Penttila, M. Hurme, and P. J. Karhunen. 2001. Polymorphisms within the tumor necrosis factor locus and prevalence of coronary artery disease in middle-aged men. Atherosclerosis 154:691-697.

Kučerová, J., A. Matějíček, O. M. Jandurová, P. Sorensen, E. Němcová, M. Štípková, T. Kott, J. Bouška, and J. Frelich. 2006. Milk protein genes CSN1S1, CSN2, CSN3, LGB and their relation to genetic values of milk production parameters in Czech Fleckvieh. Czech J. Anim. Sci. 51:241-247.

Lindström, U. B., V. Antila, and J. Syväjärvi. 1984. A note on some genetic and non-genetic factors affecting clotting time of Ayrshire milk. Acta Agric. Scand. 34:349-355.

Mancini, G., E. L. Nicolazzi, A. Valentini, G. Chillemi, P. Ajmone Marsan, E. Santus, and L. Pariset. 2013. Association between single nucleotide polymorphisms (SNPs) and milk production traits in Italian Brown cattle. Livest. Sci. 157:93-99.

Meredith, B. K., F. J. Kearney, E. K. Finlay, D. G. Bradley, A. G. Fahey, D. P. Berry, and D. J. Lynn. 2012. Genome-wide associations for milk production and somatic cell score in Holstein-Friesian cattle in Ireland. BMC Genet. 13:21.

Meuwissen, T. H., B. J. Hayes, and M. E. Goddard. 2001. Prediction of total genetic value using genome-wide dense marker maps. Genetics 157:1819-1829.

Misztal, I., S. Tsuruta, T. Strabel, B. Auvray, T. Druet, and D. Lee. 2002. BLUPF90 and related programs (BGF90). Proc. 7th World Congress on Genetics Applied to Livestock Production, Montpellier, France. CD-ROM Commun. No. 28-07.

Nilsen, H., H. G. Olsen, B. Hayes, E. Sehested, M. Svendsen, T. Nome, T. Meuwissen, and S. Lien. 2009. Casein haplotypes and their 
association with milk production traits in Norwegian Red cattle. Genet. Sel. Evol. 41:24.

Ogorevc, J., T. Kunej, A. Razpet, and P. Dovc. 2009. Database of cattle candidate genes and genetic markers for milk production and mastitis. Anim. Genet. 40:832-851.

Penasa, M., M. Cassandro, D. Pretto, M. De Marchi, A. Comin, S. Chessa, R. Dal Zotto, and G. Bittante. 2010. Short communication: Influence of composite casein genotypes on additive genetic variation of milk production traits and coagulation properties in Holstein-Friesian cows. J. Dairy Sci. 93:3346-3349.

Penasa, M., F. Tiezzi, A. Sturaro, M. Cassandro, and M. De Marchi. 2014. A comparison of the predicted coagulation characteristics and composition of milk from multi-breed herds of Holstein-Friesian, Brown Swiss and Simmental cows. Int. Dairy J. 35:6-10.

Pérez, P., and G. de Los Campos. 2014. Genome-wide regression and prediction with the BGLR statistical package. Genetics 198:483495.

Pretto, D., M. De Marchi, M. Penasa, and M. Cassandro. 2013. Effect of milk composition and coagulation traits on Grana Padano cheese yield under field conditions. J. Dairy Res. 80:1-5.

Rahmatalla, S. A., M. Reißmann, U. Mueller, and G. A. Brockmann. 2015. Identification of genetic variants influencing milk production traits in Sudanese dairy cattle. Res. J. Anim. Sci. 9:12-22.

Rahmatalla, S. A., U. Müller, E. M. Strucken, M. Reissmann, and G. A. Brockmann. 2011. The F279Y polymorphism of the GHR gene and its relation to milk production and somatic cell score in German Holstein dairy cattle. J. Appl. Genet. 52:459-465.

Riddell-Lawrence, S., and C. L. Hicks. 1989. Effect of curd firmness on stirred curd cheese yield. J. Dairy Sci. 72:313-321.

Russo, V., L. Fontanesi, M. Dolezal, E. Lipkin, E. Scotti, P. Zambonelli, S. Dall'Olio, D. Bigi, R. Davoli, F. Canavesi, I. Medugorac, M. Föster, J. Sölkner, F. Schiavini, A. Bagnato, and M. Soller. 2012. A whole genome scan for QTL affecting milk protein per- centage in Italian Holstein cattle, applying selective milk DNA pooling and multiple marker mapping in a daughter design. Anim. Genet. 43:72-86.

Tiezzi, F., D. Pretto, M. De Marchi, M. Penasa, and M. Cassandro. 2013. Heritability and repeatability of milk coagulation properties predicted by mid-infrared spectroscopy during routine data recording, and their relationships with milk yield and quality traits. Animal 7:1592-1599.

Vallas, M., T. Kaart, S. Värv, K. Pärna, I. Jõudu, H. Viinalass, and E. Pärna. 2012. Composite $\beta$ - $\kappa$-casein genotypes and their effect on composition and coagulation of milk from Estonian Holstein cows. J. Dairy Sci. 95:6760-6769.

Viitala, S., J. Szyda, S. Blott, N. Schulman, M. Lidauer, A. MäkiTanila, M. Georges, and J. Vilkki. 2006. The role of the bovine growth hormone receptor and prolactin receptor genes in milk, fat and protein production in Finnish Ayrshire dairy cattle. Genetics 173:2151-2164.

Wang, X., C. Maltecca, R. Tal-Stein, E. Lipkin, and H. Khatib. 2008. Association of bovine fibroblast growth factor 2 (FGF2) gene with milk fat and productive life: An example of the ability of the candidate pathway strategy to identify quantitative trait genes. J. Dairy Sci. 91:2475-2480.

Waters, S. M., M. S. McCabe, D. J. Howard, L. Giblin, D. A. Magee, D. E. MacHugh, and D. P. Berry. 2011. Associations between newly discovered polymorphisms in the Bos taurusgrowth hormone receptor gene and performance traits in Holstein-Friesian dairy cattle. Anim. Genet. 42:39-49.

Weikard, R., C. Kühn, T. Goldammer, G. Freyer, and M. Schwerin. 2005. The bovine PPARGC1A gene: molecular characterization and association of an SNP with variation of milk fat synthesis. Physiol. Genomics 21:1-13.

Wiggans, G. R., and G. E. Shook. 1987. A lactation measure of somatic-cell count. J. Dairy Sci. 70:2666-2672. 